\title{
AN EMPIRICAL INVESTIGATION ON THE USE OF DERIVATIVE INSTRUMENTS BY INDUSTRIAL FIRMS IN TURKEY
}

Pelin ÖZEK ${ }^{\star}$

\begin{abstract}
This study examines the factors related to the use of derivative instruments by non-financial firms in Turkey. The analysis is based on a sample of 115 firms listed on the Borsa İstanbul Industrial Index (XUSIN) between the years 2009 and 2014. Generally, it is found that derivative instruments are used by 35 percent of the sample. The results from univariate tests and logistic regression analysis show that the use of derivatives is positively associated with leverage and firm size. In addition, earnings volatility and net profit margin are negatively associated with the firm use of derivatives. However the data does not provide sufficient evidence linking the use of derivative instruments to the firm value.
\end{abstract}

Keywords: Derivative Instruments, Hedging, Firm Characteristics.

Jel Codes: G30, G32, M41

\section{TÜRKIYYE'DE ENDÜSTRIYEL FİRMALARIN TÜREV ARAÇ KULLANIMINA YÖNELIKK AMPİRIKK BİR ARAŞTIRMA}

\section{Öz}

Bu çalışmada, Türkiye'de finans sektörü dışında faaliyet gösteren firmaların türev araç kullanımı ile ilişkili faktörler analiz edilmektedir. Analizler Borsa İstanbul Sınai Endeksine (XUSIN) kayıtlı olan 115 firmanın 2009 ve 2014 yılları arasındaki verilerine dayalı olarak yapılmıştır. Genel olarak örneklemin yüzde 35’i tarafından türev araç kullanıldığı belirlenmiştir. Tek değişkenli istatistiksel testler ve lojistik regresyon analizinden elde edilen sonuçlar türev araç kullanımının kaldıraç ve firma büyüklüğü ile pozitif ilişkili

* Assist. Prof., Gaziosmanpaşa University, Faculty of Economic and Administrative Sciences, pelin.ozek@gop.edu.tr 
olduğunu göstermektedir. Ayrıca, kâr volatilitesi ve net kâr marjı firmaların türev araç kullanımı ile negatif ilişkilidir. Bununla birlikte veriler, türev araç kullanımını firma değeri ile ilişkilendirmek için yeterli kanıt sağlamamıştır.

Anahtar Kelimeler: Türev Araçlar, Risten Korunma, Firma Özellikleri.

Jel Kodları: G30, G32, M41

\section{Introduction}

With the rapid growth in derivative markets, the use of derivative instruments by nonfinancial firms has increasingly gained interest among academic researchers. Several surveys on managerial motivations behind the use of derivatives indicate different levels of derivative usage across countries. For instance, 57\% of US firms and 78\% of German firms (Bodnar and Gebhardt, 1999), 78\% of UK firms (Judge, 2006), 76\% of Australian firms (Benson and Oliver, 2004) and $66 \%$ of Belgian firms (De Ceuster et al., 2000) are documented to use derivative instruments. On the other hand, surveys in emerging or less developed countries report relatively lower levels of derivative usage. Accordingly, 34\% of Greek firms (Kapitsinas, 2008), 33\% of Peruvian firms (Martin et al., 2009), 60\% of the Jordanian firms (ALshbiel and Tahat, 2014) are found to use financial derivatives. In Turkey, the findings based on footnote disclosures (Selvi and Türel, 2010) show that $35 \%$ of the non-financial companies listed in ISE-100 Indices use derivative instruments. These results raise an important question regarding the determinants of derivative usage, especially in emerging countries.

A growing number of studies document a significant relationship between the use of derivative instruments and firm characteristics, based on the data from financial disclosures. Nguyen and Faff (2002) find that a firm's leverage, size and liquidity are the most important factors associated with the decision to use derivative instruments in Australia. According to the fndings of Heaney and Winata (2005), economies of scale, financial distress, agency costs, optimal investment, management compensation and foreign business exposure have a role to play in explaining derivative use in a sample of Australian publicly listed companies. In a more recent study, Birt et al. (2013) find that the use of derivative instruments in Australian extractives industry is positively associated with financial risk and firm size.

Moreover, Shu and Chen (2003) document that the vital determinants of a firm's use of derivatives are size, the ratio of long-term debt to total debt, the electronic industry dummy and the export ratio in Taiwan. Afza and Alam (2011) show that Pakistani non-financial firms' extent of derivatives usage is positively associated with lower financial distress costs, higher debt levels, underinvestment problem and fewer managerial holdings. Charumathi and Kota (2012) document that the major determinant of derivative usage by large Indian non-financial companies is the firm size. Ahmad and Haris (2012) find that current ratios and market-to-book value are 
the main factors influencing Malaysian non-financial companies to use derivatives. According to the findings of Raghavendra and Velmurugan (2014), size and underinvestment (price/earnings ratio) are the major determinants of the currency derivatives usage in large Indian information technology firms.

While research on the determinants of derivative usage continues, this article contributes to the existing literature by providing evidence on the relationship between the use of derivative instruments and firm characteristics for a sample of industrial firms in Turkey. In particular, this study analyzes the relationship between the use of derivative instruments and firm characteristics including earnings volatility, firm value, financial leverage, firm size and net profit margin that are proposed in prior studies. The sample consists of 643 firm-year data observations obtained from 115 firms listed on the Borsa İstanbul Industrial Index between the years 2009 and 2014. In general, it is found that derivative instruments are used by 35 percent of the sample. The results from univariate tests and binary logistic regression analysis indicate a statistically significant relationship between the use of derivative instruments and earnings volatility, leverage, firm size and net profit margin. Specifically, the use of derivative instruments is negatively associated with earnings volatility and net profit margin. In addition, leverage and firm size is positively associated with the use of derivatives. Overall, these findings provide additional support for the theoretical predictions that hedging firms tend to have lower earnings volatility, and that highly levered firms tend to hedge more to reduce the probability of financial distress.

This paper is organized as follows. Section 2 provides a review of the literature, from which the relationships between the use of derivatives and firm characteristics are hypothesized. Section 3 describes the sample selection, the dependent and independent variables and data. Section 4 provides results from univariate tests of significance and estimating logit model. The last section provides a conclusion.

\section{Literature Review}

In theory, one of the reasons to support firms' risk management activities is that risk management may reduce financial distress costs through reducing earnings volatility (Smith and Stulz, 1985). In addition to this prediction, several surveys report that one of the most important objective of firms in using derivative instruments is to manage the volatility of accounting earnings (Bodnar and Gebhardt, 1999; Prevost et al., 2000; Mallin et al., 2001).

In recent years, the empirical evidence on the relationship between the use of derivative instruments and reduced earnings volatility has become to increase. However, there is a controversy regarding the impact of accounting standards on earnings volatility. One argument asserts that the financial instruments accounting standards cause additional volatility which may result from discouraging effective hedging strategies, from the non-availability of hedge accounting or from not applying hedge accounting (Gebhardt, 2012: 282). According to Barton (2001: 2), if accounting standards increase earnings volatility, derivatives and discretionary 
accruals may be substitute means of smoothing earnings. Consistent with this view, he finds that firms holding derivatives with large amounts have lower discretionary accruals using a sample of nonfinancial Fortune 500 firms between 1994 and 1996. On the other hand, Singh (2004) doesn't support these findings using 2000-2001 data for a sample of nonfinancial Fortune 500 firms. The results of his study show no significant differences in earnings volatility, cash flow volatility and income smoothing between users and non-users of derivatives. Similarly, Zhang (2009) finds no significant change in earnings volatility after the adoption of The Statement of Financial Accounting Standard No. 133 for either effective hedgers or ineffective hedgers.

As another argument on the relationship between earnings volatility and derivatives usage, Beneda (2013) asserts that the purpose of using derivatives for hedging versus speculation should be more accurately captured by the lower/higher earnings volatility because of more sophisticated reporting rules. Analyzing the non-financial US firms over the years 2003-2010, she finds a strong association between the use of derivative instruments for cash flow hedging and reduced earnings volatility. According to Abdel-Khalik and Chen (2015: 306), the earlier findings of positive or no relationship between earnings volatility and derivatives usage may be due to the research periods when the amount of outstanding derivatives was small or research data for only one or two years following the effective date of related standard. Their sample consists of 397 bank holding companies that use derivatives for trading and/or hedging purposes between 1995 and 2012 in US. According to the findings, the use of derivatives for cash flow hedging reduces earnings volatility and firms increase their use of non-trading derivatives when facing high level of earnings volatility.

Apart from the arguments discussed above, prior studies on the relationship between derivative usage and earnings volatility also report mixed findings. Jalilvand (1999) examines the differences in the use of derivatives by 77 nonfinancial firms in Canada. According to the results, the volatility of derivative users' operating income is significantly higher than that of nonusers. On the other hand, Bartram et al. (2011) analyze the effect of derivative use on risks and value with a large sample of firms from 47 countries over 2001-2002. They find that compared to firms that do not use derivatives, users of derivatives have lower cash flow and earnings volatility suggesting that nonfinancial firms employ derivatives with the motive and effect of risk reduction, rather than speculation. Paligorova and Staskow (2014) investigate Canadian non-financial firms over 2005-2013 period and define a firm that uses derivative instruments as hedger. According to the results of the study, firms that hedge tend to have lower earnings volatility. They discuss that hedging can improve firms' capital-raising capabilities and, consequently, their investment decisions by reducing the volatility in the income stream.

Furthermore, some studies analyze the association between the use of derivative instruments and earnings volatility in the banking sector. Keffela and Peretti (2013) investigate the level of accounting risks which is faced by using derivatives with a sample of banks from emerging and recently developed countries. According to the results, options has a negative effect, but forwards and futures have positive effects on earnings volatility which is used as an indicator of banks' total risks. Similarly, Kornél (2014) analyzes whether the banks in Hungary were at risk or not 
as a result of their derivative usage during the period from 2003 to 2012 . The author finds an association between the use of derivatives and leverage, liquidity and credit risks. However, the overall risk which is measured by earnings volatility is not affected by the use of derivative instruments.

In the light of the literature, it is expected that firms that use derivative instruments have lower earnings volatility than firms that do not use derivative instruments. Therefore, the first hypothesis is developed as follows:

$\mathrm{H} 1$. The use of derivative instruments is negatively associated with earnings volatility.

As mentioned before, one of the managerial reasons for hedging with derivative instruments is that hedging reduces financial distress costs. Based on this prediction, previous studies investigate the relationship between the use of derivatives and financial distress. As an evidence of the impact of financial distress costs on hedging activities, Jalilvand (1999) shows that Canadian derivative users have higher leverage and lower credit ratings. Berkman et al. (2002) find that leverage is positively associated with the use of derivatives based on a sample of 158 Australian industrial and mining firms in 1995. Using a sample of Australian firms over 1999-2000, Nguyen and Faff (2002) report that firms with higher levels of leverage are more likely to use derivatives. According to a latter study using the same data (Nguyen and Faff; 2003), leverage is found to be an important factor that induce a firm to use financial derivatives. They conclude that highly levered firms tend to hedge more to reduce the probability of financial distress.

The studies on the use of derivative instruments also investigate the firm size as an independent variable. Jalilvand (1999) shows that firm size in an important determinant for identifying Canadian and international users of derivatives. Both Berkman et al. (2002) and Nguyen and Faff (2002; 2003) find that larger firms are more likely to use derivatives in Australia. Additionally, Charumathi and Kota (2012) investigate the determinants of derivative usage by Indian companies during 2007-2009 and find that size is the major determinant of the derivative usage. The most common explanation for this positive relationship is that larger firms have economies of scale in setting up a hedging program (Jalilvand, 1999; Berkman et al., 2002; Nguyen \& Faff, 2002; Charumathi and Kota, 2012). Based on the above findings and conceptual framework, the following hypotheses are developed:

$\mathrm{H} 2$. The use of derivative instruments is positively associated with leverage.

H3. The use of derivative instruments is positively associated with firm size.

The effect of derivative usage on firm value is also a research question which is tested by several studies empirically, but the findings are mixed. Analyzing the effect of derivative usage on firm value with a sample of firms from 47 countries during 2001-2002, Bartram et al. (2011) find that use of derivatives is associated with a value premium, however the statistical significance of this premium is weak. Fauver and Naranjo (2010) investigate the net impact of derivative usage on firm value using data on over 1.746 firms in the U.S. during 1991-2000. According to the findings, firms with greater agency and monitoring problems exhibit a negative association 
between Tobin's $Q$ and derivative usage. They conclude that derivative usage has a negative impact on firm value in firms with greater agency and monitoring problems.

Khediri (2010) employs a sample of 250 non-financial French firms over the period 2000-2002 to examine the valuation effect of derivative use. He finds that the decision to use derivatives has no effect on firm valuation, while the extent of derivative use is associated with lower firm value. However Belghitar et al. (2013) find that foreign currency derivatives use, proxied by notional amounts of derivatives, has no significant effect on firm value using a sample of the largest French non-financial firms for the years 2002-2005. Finally, using 2009 data for a sample of Swedish listed firms, Jankensgård (2015) finds that the value premium of derivative users is higher in firms with centralized foreign exchange exposure management, compared to a decentralized management. Thus, the last hypothesis of this study is as follows:

H4. The use of derivative instruments is positively associated with firm value.

\section{Methodology}

\section{I. Sample Selection}

The original sample consists of 150 firms listed on the Borsa İstanbul Industrial Index (BIST XUSIN). The research period covers the years 2009-2014. For the computation of earnings volatility, the period of 2005-2008 is also covered. Firms with missing annual observations from 2005 to 2014 (29 firms) are excluded from the sample. In addition, firms with consolidated financial statements (four firms), having a change in fiscal year-end (one firm) and which didn't have revenues (one firm) are removed from the sample. After deleting firms which have negative equity and which are smaller than 50 million Turkish liras, the sample consists of 115 firms with 643 firm-year observations. Data on the use of derivative instruments is obtained from the annual footnote disclosures between 2009 and 2014. In additon to an automated search of the annual reports, the financial statements and the footnote disclosures on derivative financial instruments are checked to classify firms as derivative users or nonusers. Financial statements and footnotes are obtained from the Borsa İstanbul (BIST) and Public Disclosure Platform web site, and data on other variables are collected from Finnet Financial Data Service (www.finnet.com.tr).

\subsection{Variables}

\subsection{Dependent Variable}

In literature, one of the measures for derivative usage is the disclosed notional amount of derivatives (Barton, 2001). The use of derivative instruments is also measured as the fair value of derivatives (Abdel-khalik and Chen, 2015). The variable based on notional values or fair values are also referred as the extent of derivative usage (Nguyen and Faff, 2002; Afza and Alam, 2011; Raghavendra and Velmurugan, 2014).

As a common measure for derivative usage, the dummy variable is used which takes a value of 1 if the firm uses derivative instruments and, 0 if the firm doesn't use derivative instruments 
(Nguyen and Faff, 2002; Fauver and Naranjo, 2010; Bartram et al., 2011; Beneda, 2013; Birt et al., 2013; Jankensgård, 2015). This study adopts the dummy variable approach which is thought to be more suitable for the sample.

\subsubsection{Independent Variables}

Jalilvand (1999) measures income volatility as the absolute value of the average rate of change in operating income over three years. Beneda (2013) measures earnings volatility as the standard deviation of eight quarters of operating returns scaled by average total assets. Abdel-khalik and Chen (2015) compute standard deviation of income before extraordinary items starting at time t over three different measurement windows, i.e., four, eight and twelve quarters, scaled by total assets. Dichev and Tang (2009) calculate earnings volatility by taking the standard deviation of the earnings deflated using average assets for the most recent 5 years. In this study, earnings volatility (EVOL) is mesaured as the standard deviation of five years of operating returns scaled by year-end total assets.

Previous studies commonly use Tobin's $\mathrm{Q}$ as a proxy for firm value. Tobin's $\mathrm{Q}$ is defined in this study as total book value of assets minus book value of equity plus market value of equity divided by total book value of assets (Fauver and Naranjo, 2010; Belghitar et al., 2013; Jankensgård, 2015).

Leverage (LEV) is computed as total debt divided by total assets to examine the association between the use of derivative instruments and financial distress. Firm size (SIZE) is measured as the natural logarithm of total assets. Finally, net profit margin (NPM) is utilized as a control variable which is computed as net income divided by net sales.

\subsection{Model and Summary Statistics}

Both univariate and multivariate analyses are conducted to examine the factors related to the use of derivative instruments. In the univariate analyses, differences in independent variables between derivative users and nonusers are tested. In the multivariate analyses, the following binary-choice logit model is estimated with the use of derivative instruments as dependent variable ( 1 for firms that use derivatives and 0 for firms that do not use derivatives):

$$
\begin{gathered}
\mathrm{P}(\mathrm{D})=\frac{1}{1+\mathrm{e}^{-\mathrm{z}}} \\
\mathrm{z}=\beta_{0}+\beta_{1} \text { EVOL }+\beta_{2} \text { Tobin's } \mathrm{Q}+\beta_{3} \mathrm{LEV}+\beta_{4} \mathrm{SIZE}+\beta_{5} \mathrm{NPM}
\end{gathered}
$$

Where:

- $\mathrm{P}(\mathrm{D})$ is the probability of using derivatives.

- $\mathrm{e}$ is the base of the natural logarithm

- $\beta_{0}$ is the constant term.

- $\beta_{1}, \beta_{2}, \beta_{3}, \beta_{4}, \beta_{5}$ are the coefficients of earnings volatility, Tobin's $Q$ ratio, leverage, firm size and net profit margin, respectively. All variables are as defined earlier. 
Table I. Descriptive Statistics

Panel A. Descriptive Statistics on Independent Variables $(\mathrm{N}=643)$

\begin{tabular}{|c|c|c|c|c|c|c|c|}
\hline & Mean & & Median & $\begin{array}{l}\text { Star } \\
\text { Dev }\end{array}$ & $\begin{array}{l}\text { dard } \\
\text { ation }\end{array}$ & $\begin{array}{l}\text { Mini- } \\
\text { mum }\end{array}$ & Maximum \\
\hline Earnings Volatility (EVOL) & 0.06 & & 0.05 & \multicolumn{2}{|c|}{0.04} & 0.00 & 0.27 \\
\hline Tobin's q & 1.46 & & 1.14 & \multicolumn{2}{|c|}{1.19} & 0.47 & 13.51 \\
\hline Leverage (LEV) & 0.43 & & 0.42 & \multicolumn{2}{|c|}{0.21} & 0.02 & 0.94 \\
\hline Firm Size (SIZE) & 19.97 & & 19.74 & \multicolumn{2}{|c|}{1.30} & 17.74 & 23.83 \\
\hline Net Profit Margin (NPM) & 0.08 & & 0.05 & \multicolumn{2}{|c|}{0.39} & -0.41 & 8.91 \\
\hline \multicolumn{8}{|c|}{ Panel B. Descriptive Statistics on Dependent Variable: DERUSE } \\
\hline & 2009 & 2010 & 2011 & 2012 & 2013 & 2014 & All Years \\
\hline Number & 33 & 36 & 40 & 40 & 33 & 40 & 222 \\
\hline \multicolumn{8}{|l|}{ Users } \\
\hline Percentage & $32 \%$ & $34 \%$ & $37 \%$ & $37 \%$ & $30 \%$ & $37 \%$ & $35 \%$ \\
\hline Number & 69 & 71 & 68 & 69 & 76 & 68 & 421 \\
\hline \multicolumn{8}{|l|}{ Nonusers } \\
\hline Percentage & $68 \%$ & $66 \%$ & $63 \%$ & $63 \%$ & $70 \%$ & $63 \%$ & $65 \%$ \\
\hline Total Number of Firms & 102 & 107 & 108 & 109 & 109 & 108 & 643 \\
\hline
\end{tabular}

EVOL is the earnings volatility measured as standard deviation of operating returns divided by yearend total assets over five years. Tobin's $Q$ is defined as book value of assets minus book value of equity plus market value of equity divided by book value of assets. LEV is the ratio of total debt to total assets. SIZE is the natural logarithm of total assets. NPM is the ratio of net income to net sales. DERUSE is the dummy variable which takes a value of 1 if the firm uses derivative instruments, 0 otherwise.

Panel A of Table 1. reports the descriptive statistics of independent variables for the full sample. The average earnings volatility for sample firms is 0.06 and, average net profit margin 
is 0.08 , indicating that many firms had positive incomes during the research period. Tobin's $\mathrm{Q}$ has a mean of 1.46. Leverage has a mean of 0.43 , indicating that sample firms' total assets are on average financed by $43 \%$ debt. Panel B of Table 1. reports firm observations across sample years 2009-2014 and subsamples based on the use of derivatives. Approximately 35\% of the 643 firm-year observations included in this study use derivative instruments. In addition, there isn't an important change in the use of derivatives across years. Table 2. presents correlation matrix for independent variables. Accordingly, there is no serious correlation between the independent variables.

Table 2. Correlation Matrix

\begin{tabular}{lccccc}
\hline Variables & EVOL & Tobin's q & LEV & SIZE & NPM \\
\hline EVOL & 1,000 & & & \\
Tobin's q & $0,114^{*}$ & 1,000 & & & \\
LEV & $-0,108^{*}$ & $0,072^{* *}$ & 1,000 & & \\
& & & & & \\
SIZE & $-0,263^{*}$ & $0,071^{* *}$ & $0,073^{* *}$ & 1,000 & \\
& & & & & \\
NPM & $-0,053$ & $0,197^{*}$ & $-0,523^{*}$ & $0,198^{*}$ & 1,000 \\
\hline
\end{tabular}

Note: ${ }^{*}$ and ${ }^{* *}$ are $1 \%$ and $10 \%$ significance levels, respectively. See Table 1 for a definition of the independent variables.

\section{Results}

\section{I. Univariate Results}

Initially, the factors related to the use of derivative instruments are investigated utilizing nonparametric Mann-Whitney tests. Specifically, users and nonusers of derivatives are compared in terms of earnings volatility (EVOL), firm value (Tobin's Q), leverage (LEV), firm size (SIZE) and net profit margin (NPM). Table 3. presents the means and medians of independent variables for derivative users and nonusers together with the p-values measuring the significance of differences between the two groups of firms. 
Table 3. Univariate Tests of Firm Characteristics and Derivative Usage

\begin{tabular}{|c|c|c|c|c|c|}
\hline \multirow[b]{2}{*}{ Variables } & \multicolumn{2}{|c|}{ Users $(n=222)$} & \multicolumn{2}{|c|}{ Nonusers $(n=421)$} & \multirow{2}{*}{ p-value } \\
\hline & Mean & Median & Mean & Median & \\
\hline EVOL & 0,043 & 0,040 & 0,062 & 0,050 & 0,000 \\
\hline Tobin's Q & 1,267 & 1,135 & 1,558 & 1,140 & 0,906 \\
\hline LEV & 0,528 & 0,545 & 0,384 & 0,350 & 0,000 \\
\hline SIZE & 20,701 & 20,565 & 19,581 & 19,460 & 0,000 \\
\hline NPM & & & & & $\begin{array}{l}0,034 \\
0,050 \\
0,101 \\
0,060 \\
0,003\end{array}$ \\
\hline $\begin{array}{l}\text { Table } 3 \text {. sh } \\
\text { racteristics } \\
\text { are shown }\end{array}$ & $\begin{array}{l}\text { e numbe } \\
\text { erivative } \\
\text { last colu }\end{array}$ & $\begin{array}{l}\text { f observa } \\
\text { ers and } n \\
\text { a. All var }\end{array}$ & $\begin{array}{l}\text { s }(\mathrm{N}) \text {, me } \\
\text { sers. P-va } \\
\text { s are defi }\end{array}$ & $\begin{array}{l}\text { d median } \\
\text { f-tailed } \\
\text { Table } 1 .\end{array}$ & $\begin{array}{l}\text { erent firm cha- } \\
\text {-Whitney tests }\end{array}$ \\
\hline
\end{tabular}

The results in Table 3. show that there is a significant difference in earnings volatility between users and nonusers of derivatives (at the 1\% level). Firms that use derivative instruments have lower earnings volatility than firms that do not use derivative instruments. This finding is consistent with the prediction that derivative usage reduces earnings volatility. Derivative users are also found to have significantly (at the 1\% level) higher leverages, indicating that firms with more debt are more likely to use derivative instruments. This finding is consistent with the prediction that highly levered firms tend to use derivative instruments to reduce the probability of financial distress.

From Table 3, derivative users are significantly (at the 1\% level) larger than nonusers, implying the existence of scale economies. In addition, derivative users have significantly (at the $1 \%$ level) lower net profit margins. Finally, results show that there isn't a statistically significant difference in the firm values between derivative users and nonusers. Overall, the results of the univariate tests provide evidence on the relationships between the use of derivative instruments and earnings volatility, leverage and firm size which are consistent with the hypotheses of this study. However firm value, contrary to predictions, doesn't have any influence on derivative usage. 


\subsection{Multivariate Results}

The factors related to the use of derivative instruments are analyzed based on the binarychoice logit model where the dependent variable takes the value of 1 if the firm uses derivative instruments, and 0 otherwise. Table 4 . summarizes the results from estimating the model (1).

Summary statistics to assess the model are reported in Panel B of Table 4 . The cutoff value is taken as 0.50 . The significance level associated with the Chi-square value for the model (204.78) is less than 0.01 rejecting the null hypothesis that all parameters in the model are equal to zero. This indicates that the fitted model is better than a null model. Hosmer and Lemeshow test of the goodness of fit suggests that the model adequately fits the data as $p=0.282(>0.05)$. According to Nagelkerke $R^{2}$, roughly $38 \%$ of the variability in dependent variable is explained by the model. Finally, of the 643 observations, the model correctly predicts $76.67 \%$ of the binary responses.

Table 4. Determinants of Derivative Usage

\begin{tabular}{|c|c|c|c|c|c|}
\hline \multicolumn{6}{|c|}{ Panel A. Logit Estimates of the Determinants of Derivative Usage } \\
\hline Model & $\begin{array}{c}\text { Pred. } \\
\text { Sign }\end{array}$ & B & S.E. & Wald & Sign. (p) \\
\hline Constant & $+/-$ & -15.568 & 1.798 & 74.954 & 0.000 \\
\hline EVOL & - & -12.898 & 3.607 & 12.788 & 0.000 \\
\hline Tobin's Q & + & -0.282 & 0.154 & 3.359 & 0.067 \\
\hline LEV & + & 3.096 & 0.560 & 30.626 & 0.000 \\
\hline SIZE & + & 0.730 & 0.087 & 70.579 & 0.000 \\
\hline NPM & $+/-$ & -2.414 & 1.115 & 4.686 & 0.030 \\
\hline \multicolumn{6}{|l|}{ Panel B. Summary Statistics } \\
\hline \multicolumn{3}{|l|}{ Number of Observations } & \multicolumn{3}{|l|}{643} \\
\hline \multicolumn{3}{|l|}{ Log likelihood } & \multicolumn{3}{|l|}{623.990} \\
\hline \multicolumn{3}{|l|}{ Model ( $\mathrm{p}$ value) } & \multicolumn{3}{|l|}{$204.78(0.00)$} \\
\hline \multicolumn{3}{|l|}{ Hosmer\&Lemeshow test } & \multicolumn{3}{|l|}{$\mathrm{p}=0.282$} \\
\hline \multicolumn{3}{|l|}{ Cox and Snell $R^{2}$} & \multicolumn{3}{|l|}{0.273} \\
\hline \multicolumn{3}{|l|}{ Nagelkerke $R^{2}$} & \multicolumn{3}{|l|}{0.377} \\
\hline \multicolumn{3}{|c|}{ Classification table-overall percentage correct } & \multicolumn{3}{|l|}{76.672} \\
\hline
\end{tabular}


Panel A of Table 4. reports the coefficient estimates and significance of independent variables. According to the results, the use of derivative instruments is negatively related to earnings volatility (EVOL) at the $1 \%$ level of significance. This result suggest that higher levels of earnings volatility increase the probability of a firm being a nonuser. The coefficients on leverage (LEV) and firm size (SIZE) are positive and significant at the $1 \%$ level, implying that firms using derivatives are characterized by higher levels of leverage and firm size compared to nonusers. The coefficient on net profit margin (NPM) is negative and significant at the 5\% level, suggesting that higher levels of net profit margin increase the probability of a firm being a nonuser. Finally, the use of derivative instruments is negatively associated with firm value (Tobin's Q), implying that higher firm value increases the likelihood of a firm to be a nonuser. However the statistical significance of this relationship is relatively weak (at the $10 \%$ level).

The negative relationship between the use of derivative instruments and earnings volatility indicates that derivative users are characterized by lower levels of earnings volatility compared to nonusers. This result seems to be consistent with prior findings that hedging firms tend to have lower earnings volatility (Beneda, 2013; Paligorova and Staskow, 2014; Abdel-Khalik and Chen, 2015). Leverage, measured as the ratio of total debt to total assets, has a positive coefficient, implying that firms with higher levels of debt are more likely to use derivative instruments. This result is consistent with prior findings (Nguyen and Faff, 2002; Berkman et al., 2002; Birt et al., 2013) and providing support for the prediction that highly levered firms tend to hedge more to reduce the probability of financial distress.

Firm size is also found to have a positive coefficient indicating that larger firms are more likely to use derivatives. A common explanation of this finding is scale economies of using derivative instruments (Nguyen and Faff, 2002; Berkman et al., 2002; Shiu, 2007; Charumathi and Kota, 2012). Accordingly, firm size proxies for a certain level of financial sophistication to use and monitor derivative instruments that larger firms already have. An alternative explanation is that large firms are more likely to operate internationally and therefore be subject to market risk associated with foreign currency fluctuations (Birt et al., 2013). Tobin's Q is the only variable which is in the opposite direction of the prediction of this study. Firms using derivative instruments are characterized by lower Tobin's Q, compared to nonusers. However, this result is relatively weak. Finally, this study doesn't have a theoretical explanation on the positive relationship between derivative usage and net profit margin, which is used as a control variable.

\section{Conclusion}

This study investigates the factors related to the use of derivative instruments. The analysis is based on a sample of 115 firms listed on the Borsa İstanbul Industrial Index between the years 2009 and 2014. Using information in annual footnote disclosures, firms are identified as derivative users and nonusers. Of 643 firm-year observations, 222 (35\%) observations are found to use derivative instruments. The univariate tests of significance and binary logistic regression analysis are conducted with the use of derivative instruments as dependent variable. 
The results of this study indicate a strong relationship between the use of derivative instruments and earnings volatility, leverage, firm size and net profit margin. The use of derivatives is negatively associated with earnings volatility. Leverage and firm size are positively associated with the use of derivatives. Additionally, use of derivatives is negatively associated with net profit margin. However there isn't adequate evidence to support the proposed relationship between derivative usage and firm value which is proxied by Tobin's q.

The main contribution of this study to the existing literature is to present evidence on the relationship between the use of derivatives and firm characteristics for a sample of industrial firms in Turkey. However there are some limitations of the study. First, firms are identified as derivative users and nonusers based on year-end reports which may cause an understatement of the actual derivative usage. Second, results based on a sample of industrial firms may limit the generalization of this study. Future studies in this area could include the other firms listed on the Borsa İstanbul. Also, an analysis based on quarterly disclosures or different proxies for both derivative usage and firm characteristics could be useful for further research. 


\section{References}

ABDEL-KHALIK, A. Rashad and CHEN, Po-Chang (2015), "Growth in Financial Derivatives: The Public Policy and Accounting Incentives", Journal of Accounting and Public Policy, 34, pp. 291-318.

AFZA, Talat and ALAM, Atia (2011), "Determinants of Extent of Financial Derivative Usage", African Journal of Business Management, 5(20), pp. 8331-8336.

AHMAD, Noryati and HARIS, Balkis (2012), "Factors for Using Derivatives: Evidence from Malaysian Non-Financial Companies", Research Journal of Finance and Accounting, 3(9), pp. 79-87.

ALSHBIEL, Seif Obeid and TAHAT, Yasean Abd Alrahman (2014), "Corporate Usage of Financial Derivatives under IAS 39 Requirements: Evidence from the Emerging Capital Market of Jordan", International Journal of Business and Social Science, 5(11), pp. 96-101.

BARTON, Jan (2001), "Does the Use of Financial Derivatives Affect Earnings Management Decisions?”, The Accounting Review, 76(1), pp. 1-26.

BARTRAM, Söhnke M., BROWN, Gregory W. and CONRAD, Jennifer (2011), “The Effects of Derivatives on Firm Risk and Value", Journal of Financial and Quantitative Analysis, 46(4), pp. 967-999.

BELGHITAR, Yacine, CLARK, Ephraim and MEFTEH, Salma (2013), "Foreign Currency Derivative Use and Shareholder Value", International Review of Financial Analysis, 29, pp. 283-293.

BENEDA, Nancy (2013), "The Impact of Hedging with Derivative Instruments on Earnings Volatility", Applied Financial Economics, 23, pp. 165-179.

BENSON, Karen and OLIVER, Barry (2004), "Management Motivation for Using Financial Derivatives in Australia”, Australian Journal of Management, 29(2), pp. 225-242.

BERKMAN, Henk, BRADBURY, Michael E., HANCOCK, Phil and INNES, Clare (2002), "Derivative Financial Instrument Use in Australia”, Accounting and Finance, 42, pp. 97-109.

BIRT, Jacqueline, RANKIN, Michaela and SONG, Chen L. (2013), "Derivatives Use and Financial Instrument Disclosure in the Extractives Industry”, Accounting and Finance, 53, pp. 55-83.

BODNAR, Gordon M. and GEBHARDT, Günther (1999), "Derivatives Usage in Risk Management by US and German Non-Financial Firms: A Comparative Survey”, Journal of International Financial Management and Accounting, 10(3), pp. 153-187.

CHARUMATHI, B. and KOTA, Hima Bindu (2012), "On the Determinants of Derivative Usage by Large Indian Non-Financial Firms”, Global Business Review, 13(2), pp. 251-267.

DE CEUSTER, Marc J.K., DURINCK, Edward, LAVEREN, Eddy and LODEWYCKX, Jozef (2000), "A Survey into the Use of Derivatives by Large Non-Financial Firms Operating in Belgium”, European Financial Management, 6(3), pp. 301-318.

DICHEV, Ilia D. and TANG, Vicki Wei (2009), “Earnings Volatility and Earnings Predictability”, Journal of Accounting and Economics, 47, pp. 160-181.

FAUVER, Larry and NARANJO, Andy (2010), "Derivative Usage and Firm Value: The Influence of Agency Costs and Monitoring Problems”, Journal of Corporate Finance, 16, pp. 719-735.

GEBHARDT, Günther (2012), "Financial Instruments in Non-Financial Firms: What Do We Know?", Accounting and Business Research, 42(3), pp. 267-289.

HEANEY, Richard and WINATA, Henry (2005), "Use of Derivatives by Australian Companies", PacificBasin Finance Journal, 13, pp. 411-430.

JALILVAND, Abolhassan (1999), “Why Firms Use Derivatives: Evidence from Canada”, Canadian Journal of Administrative Sciences, 16(3), pp. 213-228.

JANKENSGÅRD, Håkan (2015), “Does Centralisation of FX Derivative Usage Impact Firm Value?”, 
European Financial Management, 21(2), pp. 309-332.

JUDGE, Amrit (2006), "Why and How UK Firms Hedge", European Financial Management, 12(3), pp. 407441.

KAPITSINAS, Spyridon (2008), Derivatives Usage in Risk Management by Non-Financial Firms: Evidence from Greece (Unpublished doctoral thesis), University of Athens, Athens, Greece.

KEFFALA, Mohamed Rochdi and DE PERETTI, Christian (2013), "Effect of the Use of Derivative Instruments on Accounting Risk: Evidence from Banks in Emerging and Recently Developed Countries", Annals of Economics and Finance, 14(1), pp. 149-178.

KHEDIRI, Karim Ben (2010), "Do Investors Really Value Derivatives Use? Empirical Evidence from France”, The Journal of Risk Finance, 11(1), pp. 62-74.

KORNÉL, Tóth (2014), "The Effect of Derivative Financial Instruments on Bank Risks, Relevance and Faithful Representation: Evidence from Banks in Hungary". Annals of the University of Oradea, Economic Science Series, 23(1), pp. 698-706.

MALLIN, Chris, OW-YONG, Kean and REYNOLDS, Martin (2001), "Derivatives Usage in UK NonFinancial Listed Companies", The European Journal of Finance, 7(1), pp. 63-91.

MARTIN, Miguel Ángel, ROJAS, Wolfgang, ERÁUSQUIN, José Luis, YUPANQUI, Dayana and VERA, Édgar (2009), "Derivatives Usage by Non-Financial Firms in Emerging Markets: The Peruvian Case", Journal of Economics, Finance and Administrative Science, 14(27), pp. 73-86.

NGUYEN, Hoa and FAFF, Robert (2002), "On the Determinants of Derivative Usage by Australian Companies", Australian Journal of Management, 27(1), pp. 1-24.

NGUYEN, Hoa and FAFF, Robert (2003), "Further Evidence on the Corporate Use of Derivatives in Australia: The Case of Foreign Currency and Interest Rate Instruments", Australian Journal of Management, 28(3), pp. 307-317.

PALIGOROVA, Teodora and STASKOW, Rhonda (2014), "The Use of Financial Derivatives by Canadian Firms", Bank of Canada Review, Autumn, pp. 47-54.

PREVOST, Andrew K., ROSE, Lawrence C. and MILLER, Gary (2000), "Derivatives Usage and Financial Risk Management in Large and Small Economies: A Comparative Analysis”, Journal of Business Finance \& Accounting, 27(5)\&(6), pp. 733-759.

RAGHAVENDRA, R.H., and VELMURUGAN, P.S. (2014), "The Determinants of Currency Hedging in Indian IT Firms'”, Journal of Business and Financial Affairs, 3(125), pp. 1-7.

SELVI, Yakup and TÜREL, Aslı (2010), "Derivatives Usage in Risk Management by Turkish Non-Financial Firms and Banks: A Comparative Study”, Annales Universitatis Apulensis Series Oeconomica, 12(2), pp. 663-671.

SHIU, Yung-Ming (2007), "An Empirical Investigation on Derivatives Usage: Evidence from the United Kingdom General Insurance Industry”, Applied Economics Letters, 14, pp. 353-360.

SHU, Pei-Gi and CHEN, Hsuan-Chi (2003), "The Determinants of Derivatives Use: Evidence from NonFinancial Firms in Taiwan", Review of Pacific Basin Financial Markets and Policies, 6(4), pp. 473500.

SINGH, Amrik (2004), The Effects of SFAS 133 on the Corporate Use of Derivatives, Volatility, and Earnings Management (Unpublished doctoral dissertation), The Pennsylvania State University.

SMITH, Clifford W. and STULZ, René M. (1985), “The Determinants of Firms' Hedging Policies”, Journal of Financial and Quantitative Analysis, 20(4), pp. 391-405.

ZHANG, Haiwen (2009), "Effect of Derivative Accounting Rules on Corporate Risk-Management Behavior", Journal of Accounting and Economics, 47, pp. 244-264. 
